\title{
Cretaceous climatic reconstruction from Argentina based on palynological data
}

\author{
M. B. Prámparo, B. Vento, P. Narváez, N. Mego and G. G. Puebla \\ IANIGLA, CCT CONICET, Mendoza. Avda. Adrián Ruiz Leal s/n, Parque Gral San Martín, (5500) Mendoza, Argentina. \\ mprampar@mendoza-conicet.gov.ar
}

\begin{abstract}
Paleoclimatic reconstructions have used different proxies as climate indicators. In this context, palynomorphs play a crucial role for making inferences about past climate changes because of their presence and distribution during the geologic history in almost all types of environments. Argentina has a wide latitudinal range in South America, with diverse cretaceous units yielding palynomorphs that represent different climatic conditions. The Cretaceous was a time when climate conditions showed some special variations. Different theories about the climate conditions at this time were postulated. The main aim of this contribution is to understand climate trends during the Cretaceous, based on the quantitative analysis of selected pollen and spores, considered as climate indicators, from different geological units in Argentina. The evaluation of the palynofloras has been undertaken mainly by reviewing published sources from cretaceous basins but also with our own unpublished data. The climatic trend during the Cretaceous showed that the Early Cretaceous is marked by aridity episodes with high values of Classopollis and Gnetales. In contrast, the Late Cretaceous showed warmer and more humid conditions indicated by increasing values of free-sporing plants (especially Bryophytes and ferns) and palm pollen grains, and the decrease until their absence of the aridity indicators.
\end{abstract}

Keywords: Argentina, climate indicators, Cretaceous, palynomorphs.

\section{Reconstrucción climática del Cretácico de Argentina basado en datos palinológicos}

\begin{abstract}
RESUMEN
Las reconstrucciones paleoclimáticas se han llevado a cabo haciendo uso de diferentes proxies como indicadores climáticos. Teniendo en cuenta este contexto, los palinomorfos poseen un papel fundamental en el momento de realizar inferencias paleoclimáticas debido a su abundancia y distribución en diferentes unidades geológicas que abarcan prácticamente todo tipo de ambientes. Argentina tiene una gran amplitud latitudinal en Sudamérica, con diversas formaciones geológicas cretácicas que poseen registros palinológicos. Estos representan diferentes condiciones climáticas. El Cretácico fue un período en el que se han registrado variaciones climáticas. El objetivo principal de este trabajo es conocer las tendencias climáticas del Cretácico en Argentina, basándose en el análisis cuantitativo de miosporas consideradas indicadoras de ciertas condiciones climáticas, de diferentes unidades geológicas de Argentina. La evaluación de las palinofloras ha sido abordada desde la bibliografía previa publicada, así como en datos propios sin publicar. La tendencia paleoclimática durante el Cretácico muestra que el Cretácico Temprano estuvo marcado por episodios de aridez, con altos valores de Classopollis y Gnetales. Por otra parte, el Cretácico Tardío muestra condiciones de calor y mayor humedad indicadas por los valores altos de plantas de esporas libres (especialmente Briofitas y helechos) y granos de polen de palmeras, y la disminución hasta la ausencia de los indicadores de aridez.
\end{abstract}

Palabras clave: Argentina, Cretácico, indicadores climáticos, palinomorfos.

VERSIÓN ABREVIADA EN CASTELLANO

\section{Introducción}

Desde hace varios años, las reconstrucciones paleoclimáticas han tenido un papel fundamental en el momento de realizar inferencias sobre los ambientes y climas del pasado. El estudio de fósiles vegetales (macrores- 
M. B. Prámparo, et al., 2018. Cretaceous climatic reconstruction from Argentina based on... Boletín Geológico y Minero, 129 (4): $615-631$

tos y palinomorfos) es de gran importancia al contribuir en dichas reconstrucciones, siendo una de las herramientas más valiosas en este proceso. Los estudios y avances realizados en este tema, permiten afirmar que tanto los granos de polen como las esporas de algunas variedades de plantas cumplen un papel esencial como indicadores paleoclimáticos. En particular, el grupo de las Gnetales y el género Classopollis se utilizan frecuentemente como indicadores de aridez mientras que las esporas de briófitas y helechos se consideran indicadoras de humedad. El Cretácico fue un período con importantes cambios paleogeográficos y con episodios de transgresiones y regresiones marinas que podrían haber influenciado las variaciones climáticas de dicho período. En Argentina, el Cretácico se encuentra representado por una serie de formaciones geológicas, correspondientes a cuencas que se extienden de norte a sur, abarcando un amplio rango latitudinal $y$ ambiental. Además, estas formaciones muestran variadas asociaciones palinoflorísticas representativas de diferentes condiciones ambientales y climáticas.

El principal objetivo de este trabajo es contribuir al conocimiento de las tendencias climáticas durante el Cretácico, a partir de datos palinológicos registrados en diferentes unidades geológicas de Argentina, mediante un análisis cuantitativo de granos de polen y esporas fósiles previamente seleccionados como indicadores paleoclimáticos.

\section{Metodología}

Se trabajó con datos cuantitativos de dos fuentes: los datos originales de varios de los autores de este trabajo e información de conteos publicados por otros autores. Se registraron resultados de 17 formaciones geológicas localizadas en cinco cuencas de Argentina a diferentes latitudes. A partir de las asociaciones palinológicas estudiadas se seleccionaron cuatro grandes grupos que fueron utilizados como indicadores paleoclimáticos a partir de las preferencias climáticas de sus parientes actuales. Los grupos de palinomorfos seleccionados fueron: (i) esporas triletes y monoletes consideradas en este estudio como plantas con esporas libres (principalmente Bryophyta y helechos); (ii) granos de polen de palmeras como indicadores de humedad; y (iii) Classopollis y Gnetales (granos plicados tipo Ephedraceae) como indicadoras de aridez. El análisis estadístico se basó en la obtención de las abundancias relativas de los componentes de la palinoflora de cada muestra correspondiente a un nivel estratigráfico. Se consideraron conteos de entre 100 y 200 ejemplares por muestra. Los valores fueron importados al programa $R$ para la obtención de las curvas de tendencias paleoclimáticas.

\section{Resultados y Conclusiones}

El Cretácico Temprano está representado en Argentina, en las Cuencas del Grupo Salta, San Luis, Neuquén, Austral y en subsuelo plataforma externa de las áreas de Gallegos y Magallanes. Classopollis es un elemento frecuente en todas las asociaciones palinológicas del Cretácico Temprano de Argentina. Durante el Berriasiense-Valanginiense-Hauteriviense presenta valores que no superan el 50\%. Posteriormente, hacia el Barremiense, Aptiense y Albiense se observa en todas las cuencas un incremento en abundancia relativa llegando al 74\%. El grupo de las Gnetales presenta valores constantes y bajos, que no superan el 5\%, hasta el Aptiense Tardío (Formación La Cantera) donde se observa un pico del 30\%. Las plantas con esporas libres exhiben niveles de abundancia relativa entre 16-38\% en el Cretácico Temprano alcanzando algunos picos cercanos al $60 \%$ durante el Albiense.

El Cretácico Tardío se encuentra representado en este estudio por microfloras de la Cuenca del Grupo Salta (Formación Las Curtiembres), la región del Río Chubut y la Cuenca Austral. A pesar de que en este período es poco el material y los datos recopilados, se puede inferir un incremento en los valores de plantas con esporas libres y la aparición en el registro fósil de polen de palmeras que alcanza valores en promedio cercanos al $10 \%$ en el Maastrichtiense. Las Gnetales muestran un notorio pico (mayor del 50\%) en una única asociación del Campaniense en la Formación Las Curtiembres, que podría reflejar condiciones locales. Más adelante declinan en el registro. Classopollis presenta valores de menos de un $1 \%$ o está ausente en las microfloras analizadas del Cretácico Tardío.

A modo de conclusión, se puede inferir que el Cretácico fue un período con fluctuaciones climáticas destacándose picos de aridez representados por altos valores de Classopollis hacia el final del Cretácico Inferior. Por otra parte, y a pesar de que los registros del Cretácico Superior son escasos y se encuentran restringidos al Campaniense-Maastrichtiense, el marcado aumento en las abundancias relativas de las plantas con esporas libres (esto en comparación con los registros del Cretácico Inferior) junto a la frecuente presencia de polen de palmeras podría indicar para esta etapa del Cretácico condiciones cálidas y de mayor humedad.

Este trabajo constituye un primer análisis paleoclimático de la porción sur de América del Sur (Argentina) a partir de datos de abundancia relativa de palinomorfos seleccionados, con la finalidad de consolidar, con 
M. B. Prámparo, et al., 2018. Cretaceous climatic reconstruction from Argentina based on... Boletín Geológico y Minero, 129 (4): $615-631$

nuevos estudios cuantitativos, una base de datos útil para el entendimiento de las condiciones climáticas que prevalecieron durante el Cretácico.

\section{Introduction}

The Early to Mid-Cretaceous in the Southern Hemisphere is marked by strong floral provincialisms as a response to the climate conditions (Herngreen et al., 1996). Geographical changes (topography, continental position and sea level) constitute some of the most relevant mechanisms of climate change on geological time scales (Barron and Washington, 1984). General circulation models are currently producing climate simulations for the Mesozoic that correlate with the distributions of climatically sensitive facies (e.g. coals, evaporites and palaeosols) and faunal and floral distributions (e.g. reefs, crocodilians, palms, etc.) (Sellwood and Valdes, 2006). Based on negative evidence, the Mesozoic is essentially considered an ice-free time (e.g. Hallam, 1985, 1994), a warm period within which possible cooler 'snaps' existed (e.g. Price, 1999).

Regarding the Cretaceous sea-level fluctuations, Haq (2014) made an evaluation based on a synthesis of global stratigraphic data. The sea level was higher than at present, and the Late Cretaceous was characterized by very high sea levels worldwide. The curve representing the long-term envelope shows that average sea levels throughout the Cretaceous remained higher than the present day mean sea level (75-250 m above PDMSL) (Haq, 2014).

The Cretaceous climate from a general point of view was warmer than at present. A greenhouse effect, attributed to elevated levels of atmospheric $\mathrm{CO}_{2}$, caused the almost complete absence of polar ice (Frakes, 1979; Berner, 1990; Nordt et al., 2003; Skelton, 2003). More refined paleoclimate models, applied to the Cretaceous period, highlight a progressive warming from Aptian to Maastrichtian that reduced the range of annual temperature and led to low temperature gradients with values from ca. $5^{\circ} \mathrm{C}$ at the pole to ca. $30^{\circ} \mathrm{C}$ near the equator (Clarke and Jenkyns, 1999; Amiot et al., 2004; Donnadieu et al., 2006). Data from diagenetically unaltered specimens of the belemnite Dimitobelus cf. stimulus from deposits of the Río Mayer Formation at Lago San Martin (southern Argentina) suggest relatively cool temperatures for the early Albian at a palaeolatitude of approximately $58^{\circ} \mathrm{S}$ (Pirrie et al., 2004).

The beginning of the Late Cretaceous (Cenomanian-Turonian) might have been one of the warmest times of the Cretaceous driven by volcanism (Kidder and Worsley, 2012). Nordt et al. (2003) produ- ced atmospheric $\mathrm{CO}_{2}$ and temperature curves from stable $\mathrm{C}$ and $\mathrm{O}$ isotopic compositions, in paleosol carbonates between ca. 71.0 and $63.6 \mathrm{Ma}$, and demonstrated that their results correlate well with the marine isotopic record and, when taken together, point to two intense greenhouse events in the Maastrichtian.

To work out how the climate has changed over time, climate scientists need long-term records. Plants and palynomorphs are indirect data (proxy) which help us to elucidate long term climate changes. An analysis of the palynofloral content in each stratigraphic layer (sample) studied from a geological unit can tell us what types of plants were growing when the sediment was deposited. Climatic inferences can then be made based on the autoecology of fossil taxa assuming that they are similar to those of their nearest living relatives. Quantitative palynological analysis has proven to be useful for paleoclimatic reconstructions (Bruch and Mosbrugger, 2002; Liang et al. 2003). Palazzesi and Barreda (2007) concluded that there were good relationships between the major thermal character of the floras and the paleoclimatic trends from isotopic data during the Cenozoic of Patagonia. They demonstrated that a qualitative analysis based on a classical approach may well represent a general climatic pattern.

The main aim of this contribution is to evaluate whether the changes in vegetation during the Cretaceous, based on the quantitative analysis of pollen and spores associations of different geological units, from north to south Argentina, correlate with the climatic fluctuations inferred by other proxies. We analyze and compare quantitatively some selected components of the palynofloristic associations, using our own published data and some selected published sources from different geological units, from mid to high latitudes.

Climatic indicator species have been selected based on known climatic preferences of their extant relatives. Indicators of arid climates include Classopollis, ephedroid pollen grains, including elater-bearing species, while the indicators of humid climates are trilete and monolete spores, mainly produced by free-sporing plants, and palm pollen grains (Herngreen et al., 1996; Mejia-Velasquez et al., 2012).

\section{Methodology}

The quantitative data mostly come from published 
palynological studies, but also from our own unpublished data on relative abundances of selected Cretaceous palynofloras from different Argentinian basins. This study was carried out using data from 17 formations, located in five basins, from north to south (covering between $22^{\circ}$ to $54^{\circ}$ south latitude): Salta Group Basin (La Yesera Fm., Las Curtiembres Fm.); San Luis Basin (La Cantera Fm., Lagarcito Fm.); Neuquén Basin (Vaca Muerta Fm., Mulichinco Fm., Agrio Fm., La Amarga Fm., Huitrín/Ranquiles formations); Chubut River Area (Paso del Sapo Fm., Lefipán, Fm.) Austral Basin (Springhill Fm., Río Mayer Fm., Piedra Clavada Fm., Kachaike Fm., Monte Chico Fm.) (Fig. 1; Table 1). Moreover, data from three selected wells (Shell GOC-5, MLD-3 and MFJ-8) out of twelve published by Archangelsky and Archangelsky (2002, 2004) from the offshore Gallegos and Magallanes areas are also included in the discussion (Fig. 2; Table 2). The selection of these three wells was based on the number of samples with data and the depth with suggested age. The mentioned papers include detailed palynological percentages of all wells and therefore we did not plot those data here. The complete biostratigraphic discussion of the geology and stratigraphy of all the basins considered in this contribution can be found in Prámparo (2012); except for the offshore Gallegos and Magallanes data which are in Archangelsky and Archangelsky $(2002,2004)$.

We considered mainly palynodata from continental deposits but also from marginal marine geological units. The problem with some continental deposits is the lack of reliable biostratigraphic or chronostratigraphic calibration of the geologic units, and the scarcity of published statistical analysis (relative or absolute abundance of taxa) of the palynofloras. We only selected palynofloras with published quantitative data (tables or charts) and we added new unpublished data (own source) sets from Lagarcito and Agrio formations. The latitude and longitude (geographic coordinates) of the localities, the geological units, age, number of samples and complete author's refe- rences are included in Table 1. The sampling distance and stratigraphic column of each section are in the original publications cited in Table 1. In Table 2 data from three selected Shell wells from Magallanes and Gallegos area, Austral Basin are presented.

The composition of each flora was standardized in terms of four major groups using indicator pollen taxa based on the climatic preferences of its modern relatives. The chosen major groups are: free-sporing plants (mainly Bryophyta and ferns) and Palm pollen grains, considered as humidity indicators; and Classopollis and Gnetales (different Ephedra pollen type and elaterates), as indicators of aridity. Data of palynological counts obtained from bibliographic sources were compiled for a comparative purpose including a wide latitudinal range (north to south Argentina). The age of each palynological association was taken from the original published paper (radiometric datings, biostratigraphy, etc.).

For our analysis, we used the relative abundance value (from each stratigraphic horizon) that is equal to the number of specimens of a selected taxa counted in a sample, from a total of mainly 200 specimens (n). However, as we also used published data, the total number of specimens for each sample was less than 200 in some cases. The mean relative abundance was calculated for each palynoflora corresponding to a given formation, to obtain the general climatic curve trend during the Lower and Upper Cretaceous. Data consisting of relative abundance were entered in spreadsheets and a database was created. The relative abundance values were imported in $R$ program version 3.2.2 (2015) and they were used for plotting in each studied section (from the base to the top), the climatic trend/curve for each indicator in the samples, throughout the geological time (Fig.1 and Fig.2).

The aridity versus humidity climatic curve was constructed using the sum of the mean relative abundances, considering together the palms and free-sporing plants as humidity indicators and Classopollis and gnetales as aridity indicators (Fig. 3).

Figure 1. Map of Argentina showing the basins included in this study and the line graphs of the relative abundances from selected palynologic groups in each formation (for detailed information see Table 1). The distance between samples is aleatory, for stratigraphic location of the samples see the stratigraphic columns in the corresponding original publications. a) Salta Group Basin; b) San Luis Basin; c) Neuquén Basin; d) Chubut River Area; e) Austral Basin, Bajo Comisión section (lower part), Cancha Carrera and Cerro de la Cruz section (upper part); f) Austral Basin, La Horqueta section.

Figura 1. Mapa de Argentina mostrando las cuencas incluidas en este estudio y los gráficos de líneas de las abundancias relativas de grupos palinológicos seleccionados de cada formación (información detallada en Tabla 1). Las distancias entre las muestras es aleatoria, para ubicación estratigráfica de las muestras vea las columnas estratigráficas en las publicaciones originales correspondientes. a) Cuenca del Grupo Salta; b) Cuenca de San Luis; c) Cuenca Neuquina; d) Área Rio Chubut; e) Cuenca Austral, perfil Bajo Comisión; f) Cuenca Austral, Perfil La Horqueta. 


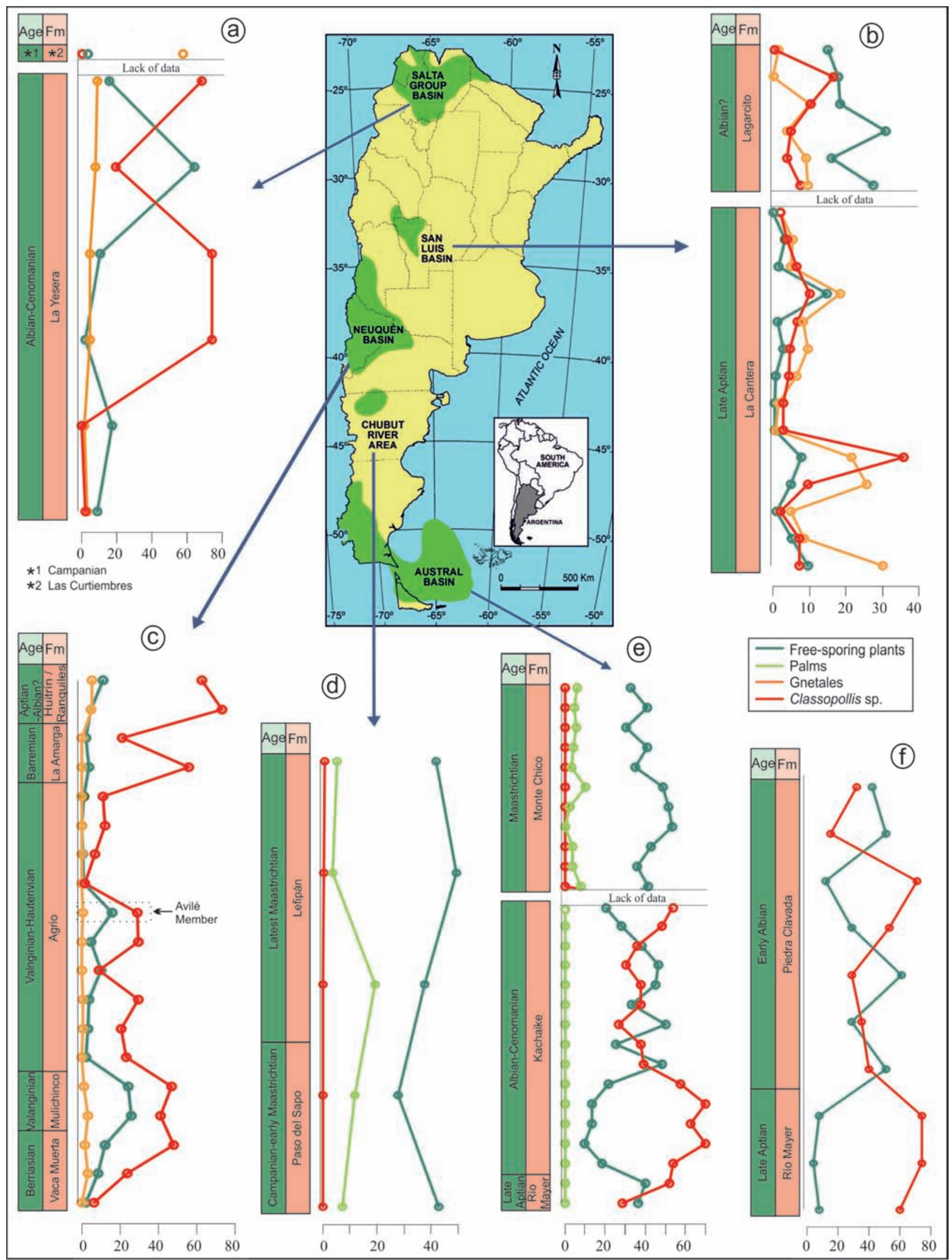


M. B. Prámparo, et al., 2018. Cretaceous climatic reconstruction from Argentina based on... Boletín Geológico y Minero, 129 (4): $615-631$

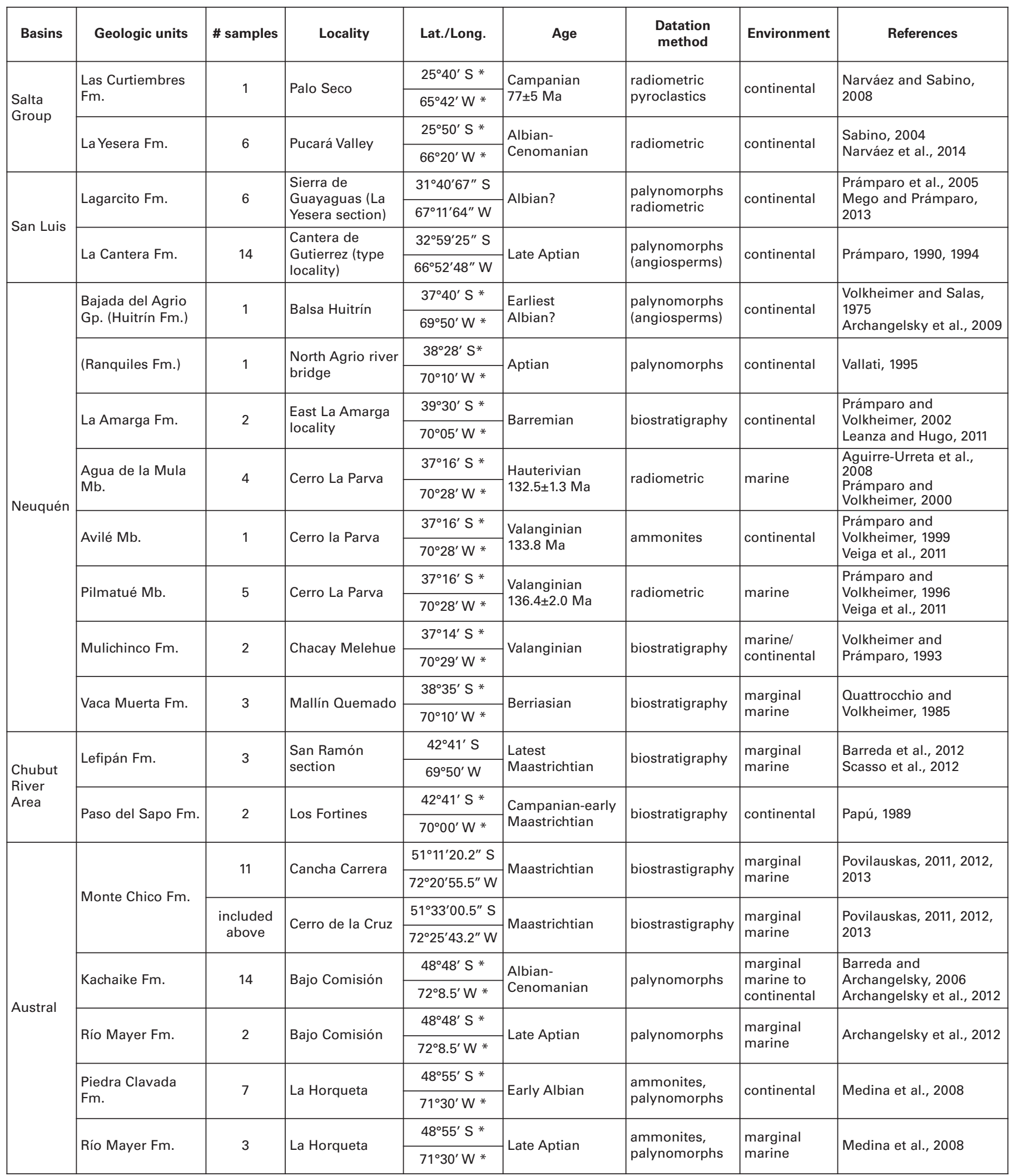

Table 1. General information of the Cretaceous palynologic associations from Argentina inlcuded in this paper. The asterisk $(*)$ indicates the geographic coordinates estimated from the location maps provided in the original publications.

Tabla 1. Información general de las asociaciones palinológicas del Cretácico de Argentina incluidas en este trabajo. El asterisco (*) indica las coordenadas geográficas estimadas a partir de los mapas de ubicación provistos por las publicaciones originales. 


\section{GOC-5 MLD-3 MFJ-8}

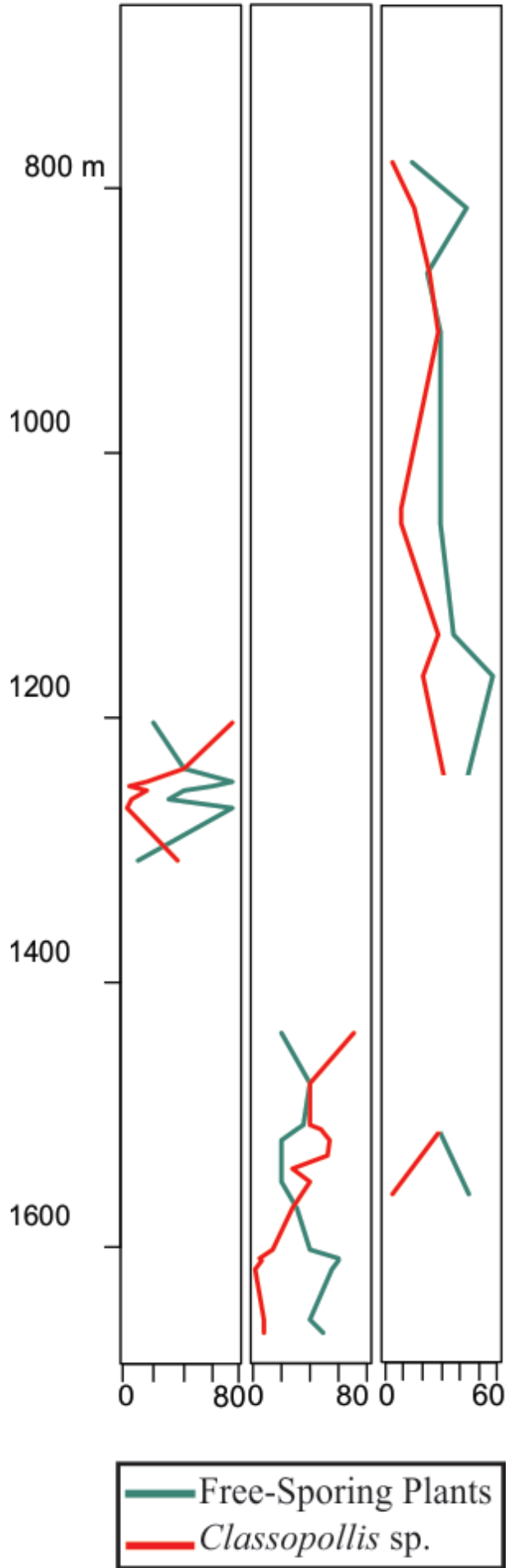

Figure 2. Line graph of the relative abundances from selected palynologic groups in samples of three wells from Austral Basin, Magallanes and Gallegos area (taken from Archangelsky and Archangelsky 2002, 2004).

Figura 2. Grafico de línea de las abundancias relativas de grupos palinologicos seleccionados de muestras correspondientes a tres pozos de la Cuenca Austral, en el área de Gallegos y Magallanes (tomados de Archangelsky and Archangelsky 2002, 2004).

\section{Selected palynological climate indicators}

\section{A) Free-sporing plants}

The Embryophyta (land plants) include Marchantiophyta (liverworts), Bryophyta (sensu stricto, mosses), Anthocerothopyta (hornworts), and Tracheophyta (Crane et al., 2004; Qiu et al., 2006). Phylogenetic studies in tracheophytes or vascular plants show a basal dicotomy that separates the lycophytes from the euphyllophytes (e.g. Kenrick and Crane, 1997; Doyle, 1998; Pryer et al., 2004). Lycophytes comprise three main clades: Lycopodiales (clubmosses), Isoetales (quillworts), and Selaginellales (spikemosses), and euphyllophytes comprise two clades: monilophytes (ferns) and spermatophytes (seed plants) (Pryer et al., 2004). Freesporing plants, as treated in this paper, include the bryophytes (sensu lato, i.e. liverworts, mosses and hornworts), lycophytes, and monilophytes. We do not use the terms "pteridophytes" or "ferns and fern allies" as they group together the lycophyte and fern clades that are paraphyletic (Pryer et al., 2004; Smith et al., 2006).

\section{Bryophytes and ferns}

Bryophytes sensu lato constitute the most diverse group of terrestrial plants after the angiosperms, with a wide diversity of habitats (Mishler, 2001). Bryophytes often inhabit temperate forests, rivers, streams, as well as tropical forests, arctic tundra, and desert rocks. Peat ecosystems are the primary habitats in which bryophytes actually dominate (Mishler, 2001). In bryophytes, the tissue is directly exposed to changes in humidity and, does not store or conduct water with anything near the efficiency of vascular plants (Richardson, 1981). This condition, combined with their ability to tolerate long periods of drought, suggests that bryophytes may be used as indicators of long-term micro climatological changes associated with fragmentation (Hylander et al., 2005). However, although bryophytes generally require a humid environment for their development, they will not survive when they are permanently submerged (Bates, 2009). Bryophytes are generally small in size and lack resistant tissues, so their fossilization is difficult. However, the spores that these produce, especially the hepatics (liverworts), have a good preservation due to their thick and sculpted wall.

The Cretaceous was a period of great importance in the evolution and dispersion of bryophytes (Taylor et al., 2009) and the hepatic species acquired great diver- 
sity and development, as demonstrated by the abundant presence of spores in almost all associations of that age (Archangelsky and Archangelsky, 2005). They are usually found in fine sediments accumulated in freshwater bodies under anaerobic conditions. Bryophyte records in the paleofloristic associations of the Lower Cretaceous in Argentina are frequent, especially at high latitudes of southern Patagonia (Archangelsky and Archangelsky, 2005) but there is also an important record (comprising micro and macro fossils) at the mid-latitude La Cantera Formation, from the San Luis Basin (Puebla et al. 2012).

Ferns are considered to be an important group during the Mesozoic (Nagalingum et al., 2002) with one of the major components being found in paleofloral assemblages (Page, 2002). It is believed that most of the fern members grew under warm conditions in moist environments during the Early Cretaceous, including wetlands, swamps, marshes, riverbanks and understory vegetation in forests (Collinson, 2002; Van Konijnenburg-van Cittert, 2002; Batten, 2007). Studies made on modern fern ecology help to point to a similar general framework in the past for fern fossils and the potential to extrapolate this information for interpretation of paleoecologic and paleoclimatic conditions (Page, 2002). Ecology advances on living ferns recognized the water availability in the environment, at least temporarily, to ensure the reproduction and conservation of the dispersed spores end even with the presence of floating structures in some genera (Collinson, 2002). A wide range of distribution from tropical to temperate climates around the world has been documented (Collinson, 2002; Page, 2002; Van Konijnenburg-van Cittert, 2002), with this available information being very useful for paleoclimatic reconstructions through the time (Page, 2002; Mejía-Velásquez et al., 2012). Free-sporing plants have been chosen in several paleoenvironmental and paleoclimatic reconstructions as indicators of moist conditions (Batten, 2007; Archangelsky et al., 2012; Mejía-Velásquez et al., 2012, Kujau et al. 2013).

Two fern families were relevant during the Lower Cretaceous: the Osmundaceae and Schizaeaceae. Currently, the Osmundaceae representatives are found worldwide with preference for swampy conditions, and being absent from cold or arid areas (Skog, 2001). Skog (2001) saw that these leptosporangiate ferns are linked to patterns of rainfall and they occur at localities between $30^{\circ}$ and $60^{\circ} \mathrm{S}$ but they do not occur in the drier belt near the equatorial regions. Throughout the Cretaceous the relative abundance of Osmundaceae steadily declined (Nagalingum et al., 2002).
Schizaeaceae, on the other hand, prefer warm, humid environments and they are mainly recorded from sandstones and clays in subtropical areas in the Northern Hemisphere. In Argentina, Del Fueyo et al. (2007) reported a high diversification of Schizaeaceae during the Hauterivian-Barremian, and diversification and abundance of Schizaeaceae and Osmundaceae during the Aptian-Albian. At the Salta Group Basin (La Yesera Fm.) the cicatricose spores are particularly abundant reaching a peak of $54 \%$ of the total assemblage (Narváez et al., 2013, 2014). From the Albian to the end of the Cretaceous, the aquatic ferns became important components of the microfloras from South America (Prámparo, 2012). The family Osmundaceae, together with Salvinaceae, are well represented in different basins in Argentina (Papú, 1997; Puebla et al., 2015; Narváez et al., 2016).

\section{B) Gnetalean pollen grains}

Gnetales is a group of gymnosperms that includes three extant monogeneric families: Ephedraceae (Ephedra L.), Welwitschiaceae (Welwitschia Hook.f.) and Gnetaceae (Gnetum L.) (Chamberlain, 1957; Bierhorst, 1971). The genus Welwitschia is endemic to the Namib Dessert and southern Angola (Kubitzki, 1990). Gnetum with pantropical distribution and the genus Ephedra is distributed in arid and semi-arid regions of the world (Kubitzki, 1990; Rydin et al., 2010; Ickert-Bond and Renner, 2016). The fossil pollen record dates back to the latest Paleozoic (e.g. Azéma and Boltenhagen, 1974; De Lima, 1980; Wang, 2004), and becomes more common since the Triassic (Rydin and Hoorn, 2016). However, polyplicate pollen grains resembling Ephedra and Welwitschia, also referred as "ephedroid or gnetalean pollen grains", are frequent and geographically widespread in the Mesozoic record especially during the Cretaceous. In this period, ephedroid pollen grains were more diverse in morphology and much more abundant in the paleofloras than they are today (Rydin and Hoorn, 2016). Modern Ephedra is adapted to dry environments and its abundance in Cretaceous sediments could be related to warmer and drier environments developed in tropical and subtropical regions during the Cretaceous (Scotese et al., 1999; Wang and Zheng, 2010). Schrank (2010) suggested, based on the analysis of modern plant dispersion, that even in low percentages the fossil Ephedra- and Welwitschia-like pollen may indicate the presence of gnetalean plant associations in dry places, not far from the site of sedimentation. A high abundance of characteristic ephedroid polyplicate pollen grains is recorded in 
Cretaceous floras from northern and central South America (e.g. Herngreen, 1973; De Lima, 1980; Pons, 1988; Herngreen and Dueñas Jimenez, 1990). Furthermore, the rich morphological variety of polyplicate palynomorph with straight or twisted ridges belonging to the ephedroid type is a characteristic feature of the African-South American Cretaceous microfloral province (Herngreen and Dueñas Jimenez, 1990). Ephedroid polyplicate (gnetalean) pollen grains are present in nearly all the Lower Cretaceous palynofloras from Argentina with different numbers of specimens, represented by: Ephedripites, Steevesipollenites, Gnetaceaepollenites, Galeacornea, etc.

\section{C) Classopollis (Cheirolepidiaceae)}

The Cheirolepidiaceae is an extinct conifer family with oldest fossil remains dating back to the Late Triassic (e.g. Ash, 1973; Axsmith et al., 2004) and which disappeared by the Cretaceous-Paleogene boundary, except in Patagonia Argentina where they were also recorded in the early Paleogene (Barreda et al., 2012). The highest diversity of the family is recorded at low paleolatitudes during the mid-Mesozoic (Alvin, 1982). Cheirolepidiacean pollen grain Classopollis, has been recorded in most southern Gondwanic palynofloras (e.g. Antarctica: Cantrill and Poole, 2002; South America: Quattrocchio et al., 2011; Africa: Bamford, 2004; and Australia: Tosolini et al., 2015). Although Classopollis has generally been considered a background element of these associations, there are some assemblages where they are a dominant component (e.g. McLoughlin et al., 2014; Villar de Seoane and Archangelsky, 2014). Macrofossil remains with morphological features, such as diminutive leaves, leaf imbrication and thick cuticles with papillate protection of deeply sunken stomata, have been found in association with sediments of semi-arid, coastal environments or disturbed areas subject to repeated volcanic ash fall (Watson, 1977; Upchurch and Doyle, 1981; Alvin, 1982; Archangelsky and Taylor, 1986). However, other studies have shown that Cheirolepidiaceae were thermophilic plants that grew under a wider range of environmental conditions but avoided swamped lowlands (Vakrameev, 1981). Regarding pollen grains, Classopollis is a characteristic and abundant element of Cretaceous low-latitude regions (Alvin, 1982), and has been generally considered indicator of well-drained soils and warm climates (Srivastava, 1976; Vakrameev 1981), but it is also present in high latitude assemblages indicative of cooler conditions (e.g. southern Australia; Tosolini et al., 2015). Classopollis is a frequent to abundant component of early Cretaceous palynofloras from Argentina, decreasing in number towards the Campanian-Maastrichtian.

\section{D) Palm pollen grains}

Palms have 190 genera with 2,000 species, distributed across the warm climates of the world, being important and typical plants of tropical sites (Dransfield and Uhl, 1998; Simpson, 2006). Palms are excellent indicators of palaeoclimatic conditions, because they are a typical family with a subtropical and tropical distribution, and they commonly grow in areas where the mean annual temperature is higher than $10^{\circ} \mathrm{C}$, with mean temperatures in the coldest month being more than $5^{\circ} \mathrm{C}$ (Greenwood and Wing, 1995; Harley, 2006).

In southern South America, palms became important representatives of the vegetation since the Late Cretaceous. However, Martínez et al. (2016) recently recorded findings of Spinizonocolpites-type tetrads with unequivocal palm affinity (Calamoideae) in the upper Barremian of Patagonia, Argentina (high latitudes) thus extending back in time the oldest known records of palm pollen in Gondwana. Nevertheless, the oldest Mesozoic palms are present in very low numbers masked by a flora dominated by conifers, cycads, Bennettitales, pteridosperms and ferns. Herngreen (1980) established the Late Cretaceous Palmae Province of Africa and northern South America. The assemblages on both sides of the Atlantic are characterized by the increasing number (10-50\%) of monocolpate Palmae types of the psila/Retimonocolpites plexus, Longapertites and morphological similar species.

Palms played a significant role in late Maastrichtian communities from South America. The Maastrichtian palynological association of the Lefipán $\mathrm{Fm}$. in Argentina represents a fern-angiosperm dominated community, with gymnosperms (podocarps) as common trees, diverse Proteaceae, aquatic ferns, and abundant palms represented by Spinizonocolpites, Arecipites, Longapertites, suggesting warm and humid adapted vegetation (Barreda et al., 2012). The presence in the palynofloras of the genus Spinizonocolpites, related to the tropical mangrove palm Nypa, would indicate specialized shore-line mangrove vegetation in the sedimentation area corresponding to Lefipán Fm. (Barreda et al., 2012).

Continental elements dominate the palynoflora of the Monte Chico Fm. Among angiosperms the palm pollen grains of the Arecaceae are abundant (2.2 to $10.4 \%$ in the different studied samples; Fig. 1) repre- 
M. B. Prámparo, et al., 2018. Cretaceous climatic reconstruction from Argentina based on... Boletín Geológico y Minero, 129 (4): $615-631$

sented by Arecipites minutiscabratus, Longapertites patagonicus (Povilauskas, 2013).

\section{Stratigraphic variation of Cretaceous climate indica- tors in the different basins}

The relative abundance of selected palynomorphs, considered as climate indicators, of 122 samples from different basins from northern to southern Argentina, were analyzed. According to these results, several peaks of dry and warm-humid conditions can be observed during the Early and Late Cretaceous of Argentina (Fig. 1 and Fig.2).

The basal Cretaceous is well represented in our data by the palynofloras of the Neuquén Basin, between $35^{\circ}$ to $39^{\circ} \mathrm{S}$ latitude (Fig. 1.c). Free-sporing plants, Gnetalean and Classopollis were components of the palynofloras of this basin. Classopollis showed relative abundance not exceeding $50 \%$ of the total, in the Berriasian-Valanginian Vaca Muerta and Mulichinco formations (Quattrocchio and Volkheimer, 1985; Volkheimer and Prámparo, 1993). The curve shows a decrease of Classopollis during the mid Valanginian-Hauterivian in accordance with the marine conditions of the Agrio Fm. (Prámparo and Volkheimer, 1999; and unpublished data) mainly at the top Agua de la Mula Member, with percentages going from 1.6 to $12 \%$. Higher in the stratigraphic column of the Neuquén Basin (Barremian through Albian) there is a peak of $55-73 \%$ of Classopollis at the La Amarga (Prámparo and Volkheimer, 2002) and Huitrín/Ranquiles formations (Volkheimer and Salas, 1975). Ephedroid pollen grains (Gnetales) are present in very low percentages (1-3\%) in Vaca Muerta and Mulichinco formations (Berriasian-Valanginian); slightly increasing (5\%) in Huitrín/Ranquiles $\mathrm{fms}$. (Aptian-earliest Albian?). Free-sporing plants reached the higher value of $26 \%$ at the Valanginian Mulichinco $\mathrm{Fm}$. and showed lower values during the Hauterivian (less than 1\%).

At the San Luis Basin (central-western Argentina, between $31^{\circ}$ to $33^{\circ} \mathrm{S}$ latitude), the Aptian-Albian is well recorded with the microfloras of the La Cantera and Lagarcito formations (Fig. 1.b). The La Cantera Fm. (late Aptian) showed a peak of $35.8 \%$ of Classopollis together with high abundance of gnetalean reaching $29.6 \%$ at the lower part of the section. Those values decrease upward in the stratigraphic column to values of $0.5-16.5 \%$ (Classopollis) and 1.5$10 \%$ (Gnetalean) during the Albian (Lagarcito Fm.). On the other hand, free-sporing plants showed the highest value of $14.8 \%$ at the Aptian (La Cantera Fm.; Prámparo 1990, 1994) and reached a peak of abun- dance of $31 \%$ at the early Albian (Lagarcito Fm.; Prámparo et al., 2005; Mego and Prámparo, 2013) in this basin.

We analyzed published results (Medina et al., 2008; Povilauskas, 2011, 2012, 2013; Archangelsky et al., 2012;) from the late Aptian-Cenomanian Bajo Comisión and late Aptian-early Albian La Horqueta sections (Río Mayer, Kachaike and Piedra Clavada formations) and the Maastrichtian, Cancha Carrera and Cerro de la Cruz sections (Río Chico Fm.) from the Austral Basin, located between $47^{\circ}$ to $54^{\circ} \mathrm{S}$ latitude (Figs. 1.e-f). At the base of the Bajo Comisión section (Río Mayer Fm.) values of Classopollis were relatively high $(28.7$ to $74 \%$ ) as well as at the Piedra Clavada (early Albian) and Kachaike (Albian-Cenomanian) formations, where the values varied from $15-71 \%$ and 26.7-70\% respectively (Fig 1.e-f). This result is coincident with the tendency of high values of Classopollis recorded near the Aptian-Albian in the Neuquén Basin (Fig. 1.c). Free-sporing plants have the opposite trend than that observed in Classopollis, showing the lowest values of $4-8 \%$ at the Río Mayer Fm. in La Horqueta section (Fig. 1.f) and increasing the abundance with a peak of $61 \%$ at the Piedra Clavada Fm. From the same basin, Povilauskas $(2011,2012,2013)$ published a complete analysis with statistical data of the Río Chico Fm. microflora (Maastrichtian). In this microflora free-sporing plants are abundant (30-53\%) and palm pollen grains reach a peak of $10 \%$. Classopollis was described and illustrated by Povilauskas (2012) as appearing in the Río Chico Fm., also mentioning a $15-18 \%$ of abundance in the association. Nevertheless, the author did not consider the rimulate grains in the final statistical counts from the Río Chico Fm. (Povilauskas, 2013) which we used for plotting Figure 1.e. Regarding the records of free-sporing plants in the Austral Basin, trilete and monolete spores reach a peak of abundance of $60 \%$ in Piedra Clavada Fm. (La Horqueta section, early Albian; Fig. 1.f) and $50 \%$ in Kachaike Fm. (Bajo Comisión section, Albian-Cenomanian?; Fig. 1.e) (Medina et al., 2008; Archangelsky et al., 2012).

The subsurface palynodata from the Austral Basin, offshore Magallanes and Gallegos areas (between $52^{\circ}$ to $53^{\circ}$ south latitude; Fig.2, Table 2), correspond to the Valaginian-Maastrichtian? interval (Archangelsky and Archangelsky, 2002, 2004). Classopollis occurs at the base of well Shell MLD-3 with percentages of $1-13 \%$ (1603-1665m; Springhill Fm., Valanginian-Hauterivian?, according to Archangelsky and Archangelsky, 2002) and reaches $71 \%$ towards the top $(1499 m$, Baqueró Group?). Trilete and monolete spores show a maximum of $39-58 \%$ at the base $(1610-1665 \mathrm{~m})$, decreasing in abundance towards the top and reaching the 
M. B. Prámparo, et al., 2018. Cretaceous climatic reconstruction from Argentina based on... Boletín Geológico y Minero, 129 (4): $615-631$

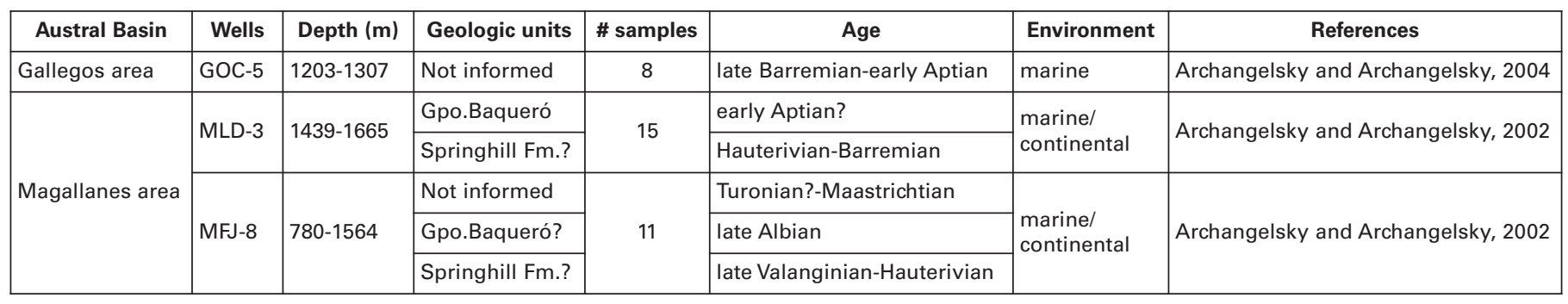

Table 2. General information of the three Shell wells selected from Archangelsky and Archangelsky (2002, 2004), Austral Basin, Magallanes and Gallegos areas, Argentina. They are arranged based on the location in the area, from north (GOC-5) to south (MLD-3, MFJ-8).

Tabla 2. Información general de los tres pozos de Shell seleccionados de Archangelsky and Archangelsky (2002, 2004), Cuenca Austral, áreas de Magallanes and Gallegos, Argentina. Los pozos están ordenados según su posición en el área, de norte (GOC-5) a sur (MLD-3, MFJ-8).

lowest percentage (12\%) at $1439 \mathrm{~m}$ (Baqueró Group?). In the well Shell GOC-5 (late Barremian-early Aptian?), Classopollis is present with $36 \%$ at the base $(1307,4 \mathrm{~m})$, decreases in abundance to $3-5 \%(1268-$ $1251 \mathrm{~m})$, and reaches its maximum abundance of $72 \%$ towards the top $(1203 \mathrm{~m})$. Spores show two peaks of $70 \%$ at $1269 \mathrm{~m}$ and $1247,7 \mathrm{~m}$ (Archangelsky and Archangelsky, 2004). Finally, at well Shell MFJ-8, rimulate grains are represented in all the samples, but at the interval of $1055-1250$ m (late Albian-late Cenomanian?) Cassopollis reaches a maximum of abundance (32\%) just at the base and then decreases; above $1044 \mathrm{~m}$ increases again to percentages of 17$27 \%$ (Turonian?). The spores on the other hand, occur with a peak of abundance of $53 \%$ at $1170 \mathrm{~m}$ (late Albian-late Cenomanian?) (Archangelsky and Archangelsky, 2002).

The Salta Group Basin, between $22^{\circ}$ to $26^{\circ} \mathrm{S}$ latitude (Fig. 1.a) palynologic records correspond to the Albian-Cenomanian period (La Yesera Fm.; Narváez et al. 2014) and part of the Campanian (only one sample from the Las Curtiembres Fm.; Narváez and Sabino, 2008). Free-sporing plants are present with values less than $20 \%$ at the lower part of the La Yesera Fm. increasing upward and reaching values of more than $60 \%$ in the upper part of the section. Classopollis showed three notorious peaks with more than $68 \%$ of relative abundance (maximum percentage of $74 \%$ ) and Gnetalean values are almost constant in all the samples from La Yesera Fm. with less than 9\%. Nevertheless, this group of plants showed a notable peak of abundance in the Las Curtiembres Fm. (57.5\%) together with an absence of Classopollis and low abundance of free-sporing plants $(3 \%)$, probably representing local arid conditions (and being cautious as these results correspond to a unique sample).

Finally, partial Upper Cretaceous is well represented at Chubut River area, between $42^{\circ} 35^{\prime}$ to $43^{\circ} \mathrm{S}$ lati- tude (Fig. 1.d; Patagonia, Argentina), with two published palynofloras: Paso del Sapo Fm. (Papú, 1989) and Lefipán Fm. (Barreda et al., 2012); both with records of relative abundance of free-sporing plants, Classopollis and Palms pollen grains. The Campanian and Maastrichtian in this area is characterized by the presence of free-sporing plants showing high values between 28 and 49\%, Classopollis values on the other hand do not exceed $1 \%$ in the Lefipán $\mathrm{Fm}$, and palms have percentages between 3.6 to $19.4 \%$ in this basin.

\section{Discussion}

To date, there are only a few papers dealing with Cretaceous paleoclimatic reconstructions based on palynomorphs from the Southern Hemisphere. De Lima (1983) published a paleoclimatic reconstruction of the Brazilian Cretaceous (low latitudes) based on palynological data. He inferred a hot, wet climate for the most basal Cretaceous, probably subtropical. For the Aptian, he suggested a hot climate with a tendency toward more arid conditions to the late Aptian. During the Albian, palynological assemblages reflecting xerophytic conditions dominated, making the Albian the most arid part of the entire Cretaceous. This tendency is in accordance with our results from the mid and low latitude palynofloras (Neuquén Basin: Huitrín Fm.; San Luis Basin: La Cantera and Lagarcito fms., Salta Group Basin: La Yesera Fm; Figs. 1 and 2), with aridity indicators showing the highest values. Nevertheless, Mejía-Velásquez et al. (2012) analyzed quantitative palynological data from stratigraphic sequences in tropical South America and concluded that there were humid climates in northern South America during the Aptian-Albian interval. Finally, for the late Senonian, De Lima (1983) evidenced warm but more humid conditions toward the end 


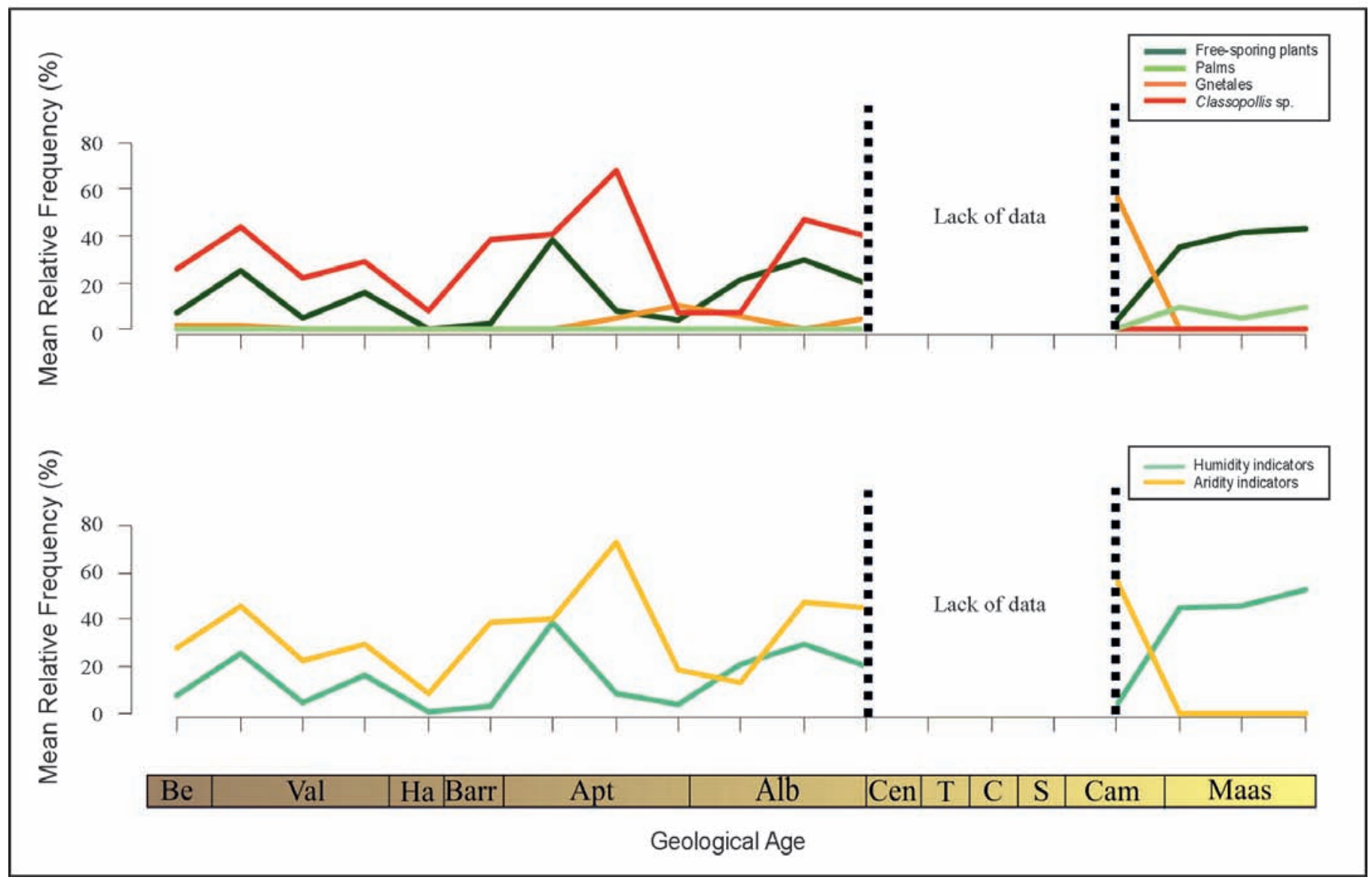

Figure 3. Line graphs showing the mean relative abundances of selected palynologic groups for each formation studied from the outcropping sections (upper) and humidity versus aridity palynologic indicators grouped into two curves (lower). (Data from the wells of the Austral Basin were not taken into account for this graphic).

Figura 3. Gráficos de línea mostrando los promedios de abundancias relativas de grupos palinológicos seleccionados de cada formación estudiada de las secciones aflorantes (arriba) e indicadores palinológicos de humedad versus aridez agrupados en dos curvas (abajo). (Los datos obtenidos de los pozos de la Cuenca Austral no fueron tomados en cuenta para este grafico).

of the Cretaceous, in which he observed a general cooling (in a relative sense). In our samples, this trend to moist conditions is evidenced by the increasing abundance of free-sporing plants together with abundant palm pollen grains (Paso del Sapo, Lefipán, and Monte Chico formations; Figs. 1 and 3 ) in the Maastrichtian.

Several authors (Dettmann, 1986; Cantrill and Poole, 2002) observed a steep floristic gradient throughout South America and the Antarctic Peninsula related to a strong latitudinal climatic gradient. For example, during the Aptian, Classopollis rarely accounts for more than $5 \%$ of the total palynoflora in the Antarctic Peninsula or is absent; the same pattern is repeated for the group of Gnetales including Elaterate grains (Cantrill and Poole, 2002). However, peaks of more than $75 \%$ of Pteridophytes-Lycophytes-
Bryophytes can be observed during the Aptian to the Cenomanian in Antarctica, indicative of the more humid conditions for these latitudes. Considering the quantitative palynological data for the Cretaceous in Argentina, a marked latitudinal paleofloristic gradient could not be observed between northern and southern microfloras. From the Aptian- to the Cenomanian the Classopollis peaks of abundance (reaching $70 \%$ or more) occur at high latitudes (Austral Basin, e.g. Kachaike Fm.) and at low latitudes (Salta Group Basin, e.g. La Yesera Fm.) (Fig. 1).

\section{Conclusions}

There are still many questions related to the Cretaceous climatic conditions in southern South 
America. The present contribution constitutes a first palaeoclimatic analysis of the southern portion of South America (Argentina), based on data of relative abundance of selected palynomorphs. From our preliminary results, we can conclude that there is a good relationship between the quantitative distributions of some selected palynomorphs and the global paleoclimatic trends, from different proxies (e.g. isotopes) for the Cretaceous.

The Cretaceous in Argentina was a time when the climatic conditions were not uniform showing some fluctuations throughout this geological time. Classopollis is a frequent component of all the Berriasian-Hauterivian palynofloras from the Neuquén Basin, with relative abundances reaching $48 \%$ of the total palynomorphs (Fig. 2) and less represented at subsurface offshore in the Magallanes and Gallegos areas (high latitudes). The palynofloras from all the studied basins show a gradual aridity trend (increase of the abundance of aridity indicators) during the Aptian-early Albian with some notorious peaks in Classopollis abundance (Fig. 2) including those associations of high latitudes. There is evidence of an expanding warm arid belt characterized by increased abundance of the drought-resistant conifer pollen Classopollis and gnetalean pollen together with reduced abundance of free-sporing plants, during the Aptian-Albian at mid and low latitudes of Argentina.

By the Campanian-Maastrichtian, the abundance of palm pollen grains together with increasing number of free-sporing plants (compared with the Early Cretaceous palynofloras) would suggest warm and more humid conditions.

Nevertheless, statistical data about Cretaceous palynofloras are still scarce and incomplete. Further quantitative analysis of palynofloras from Argentina is necessary to better understand and identify the climatic trends during the Cretaceous.

\section{Acknowledgements}

This work has been supported with grants provided by CONICET (PIP 11220130100444 CO, M. Prámparo and P. Narvaez) and Agencia Nacional de Promoción Científica y Tecnológica (PICT 1340-2015, N. Mego). We are grateful to Dr. Josué M. Polanco-Martinez for inviting us to present this contribution for the special volume "Paleoclimas en Iberoamerica" and to the reviewers A. Archangelsky and E. Barrón for the suggestions that improved the manuscript. Thanks to the technician A. Moschetti for the palynological preparation of the samples from the Neuquén and Salta
Group basins, and the Huitrín Formation, and to R. Bottero for digital assistance with the map in Figure 1.

\section{References}

Aguirre-Urreta, M.B., Pazos, P.J., Lazo, D.G., Fanning, C.M. and Litvak, V.D. 2008. First U-PBSHRIMP age of the Hauterivian stage, Neuquén Basin, Argentina. Journal of South American Earth Sciences, 26, 91-99.

Alvin, K.L. 1982. Cheirolepidiaceae: biology, structure and paleoecology. Review of Palaeobotany and Palynology, 37, 71-98.

Amiot, R., Lécuyera, C., Buffetaut, E., Fluteau, F., Legendre, S. and Martineau, F. 2004. Latitudinal temperature gradient during the Cretaceous Upper Campanian-Middle Maastrichtian: $\mathrm{O}_{18}$ record of continental vertebrates. Earth and Planetary Science Letters, 226, 255-272.

Archangelsky, S. and Archangelsky, A., 2002. Palinología estadística en el Cretácico de la Cuenca Austral. Plataforma Continental Argentina. I. Seis perforaciones del área de Magallanes. Revista del Museo Argentino de Ciencias Naturales n.s.. 4, 25-34.

Archangelsky, S. and Archangelsky, A., 2004. Palinología estadística en el Cretácico de la Cuenca Austral. Plataforma Continental Argentina. II. Seis perforaciones del área Gallegos. III. Discusión y conclusiones. Revista del Museo Argentino de Ciencias Naturales n.s.. 6, 245-255.

Archangelsky, S. and Archangelsky, A. 2005. Aequitriradites Delcourt \& Sprumont y Couperisporites Pocock, esporas de hepáticas, en el Cretácico Temprano de Patagonia, Argentina. Revista del Museo Argentino de Ciencias Naturales nueva serie, 7, 119-138.

Archangelsky, S., Archangelsky, A. and Cladera, G. 2012. Palinología y paleoambientes en el perfil de Bajo Comisión (Cretácico), provincia de Santa Cruz, Argentina. Revista del Museo Argentino de Ciencias Naturales, 14 (1), 23-39.

Archangelsky, S., Barreda, V., Passalia, M.G., Gandolfo, M.A., Prámparo, M.B., Romero, E.J., Cuneo, R., Zamuner, A., Iglesias, A., Llorens, M., Puebla, G.G., Quattrocchio, M. and Volkheimer, W. 2009. Early Angiosperm diversification: Evidence from southern south América. Cretaceous Research, 30, 1073-1082.

Archangelsky, S. and Taylor, T.N. 1986. Ultrastructural studies of fossil plant cuticles. II Tarphyderma gen. n., A Cretaceous conifer from Argentina. American Journal of Botany, 73, 1577-1587.

Ash, S.R. 1973. Two new Late Triassic plants from the Petrified Forest of Arizona. Journal of Paleontology, 47, 46-53.

Axsmith, B.J., Krings, M. and Waselkov, K. 2004. Conifer pollen cones from the Cretaceous of Arkansas: implications for diversity and reproduction in the Cheirolepidiaceae. Journal of Paleontology, 78, 402-409.

Azéma, C. and Boltenhagen, E. 1974. Pollen du Crétacé moyen du Gabon attribué aux Ephedrales Paléobiologie continentale, 5 (1), 1-37. 
Bamford, M.K. 2004. Diversity of the woody vegetation of Gondwanan southern Africa. Gondwana Research, 7, 153-164.

Barreda, V. and Archangelsky, S. 2006. The southernmost record of tropical pollen grains in the mid-Cretaceous of Patagonia, Argentina. Cretaceous Research, 27 (6), 778787.

Barreda, V., Cuneo, N.R., Wilf, P., Currano, E.D., Scasso, R., Brinkhuis, H., 2012. Cretaceous/Paleogene floral turnover in Patagonia: drop in diversity, low extinction, and a Classopollis spike. PLoS ONE 7, 12, e52455.

Barron, E.J., Washington, W.M. 1984. The role of geographic variables in explaining paleoclimates: results from Cretaceous climate model sensitivity studies. Journal of Geophysical Research, 89, 1267-1279.

Bates, J.W. 2009. Mineral nutrition and substratum ecology. In: Goffinet B. and Shaw, A.J. (eds.). Bryophyte biology. Cambridge University Press, New York, 299-356.

Batten, D.J. 2007. Spores and pollen from the Crato Formation: biostratigraphic and palaeoenvironmental implications In: Martill, D.M., Bechly, G. and Loveridge, R.F. The Crato fossil beds of Brazil: window into an ancient world. Cambridge University Press, Cambridge, 566-573.

Berner, R.A. 1990. Atmospheric carbon dioxide levels over Phanerozoic time. Science, 249, 1382-1386.

Bierhorst, D.W. 1971. Morphology of vascular plants. MacMillan Company, New York, 560 pp.

Bruch, A.A. and Mosbrugger, V. 2002. Palaeoclimate versus vegetation reconstruction palynological investigations on the Oligocene sequence of the Sava Basin, Slovenia. Review of Palaeobotany and Palynology, 122, 117-141.

Cantrill, D.J. and Poole, I., 2002. Cretaceous patterns of floristic change in the Antarctic Peninsula. In: Crame, J.A. and Owen, A.W. (eds.). Palaeobiogeography and biodiversity change: the Ordovician and MesozoicCenozoic radiations. Geological Society, London, Special Publications, 194, 141-152.

Chamberlain, C.J. 1957. Gymnosperms, structure and evoIution. Johnson Reprint Corporation, New York, 484 pp.

Clarke, L.J. and Jenkyns, H.C. 1999. New oxygen isotope evidence for long-term Cretaceous climatic change in the Southern Hemisphere. Geology, 27, 699-702.

Collinson, M.E. 2002. The ecology of Cainozoic ferns. Review of Palaeobotany and Palynology, 119 (1), 51-68.

Crane, P.R., Herendeen, P. and Friis, E.M. 2004. Fossils and plant phylogeny. American Journal of Botany, 91, 1683-1699.

De Lima, M.R. 1980. Palinologia da Formação Santana (Cretáceo do Nordeste do Brasil). III-Descrição sistemática dos polens da turma Plicates (subturma Costates). Ameghiniana, 17, 15-47.

De Lima, M.R. 1983. Paleoclimatic reconstruction of the Brazilian Cretaceous based on palynological data. Revista Brasileira de Geociencias, 13, 223-228.

Del Fueyo, G.M., Villar de Seoane, L., Archangelsky, A., Guler, V., Llorens, M, Archangelsky, S., Gamerro, J.C., Musacchio, E.A., Passalia. M.G. and Barreda, V.D. 2007 Biodiversidad de las paleofloras de Patagonia austral durante el Cretácico Inferior. Ameghiniana, Publicación Especial, 11, 101-122.

Dettmann, M.E. 1986. Early Cretaceous palinoflora of subsurface strata correlative with the Koonwarra Fossil Bed, Victoria. Australiasian Association of Palaeontologists Memoir, 3, 79-110.

Donnadieu, Y., Pierrehumbert, R., Jacob, R. and Fluteau, F. 2006. Modelling the primary control of paleogeography on Cretaceous climate. Earth and Planetary Science Letters, 248, 426-437.

Doyle, J.A. 1998. Phylogeny of vascular plants. Annual Review of Ecology and Systematics, 29, 567-599.

Dransfield, J. and Uhl, N. 1998. Palmae. In: Kubitzki, K. (ed.), Families and genera of vascular plants, Volume IV, Flowering plants: Monocotyledons: Alismatanae and Commelinanae. Springer-Verlag, Berlin, 306-389.

Frakes, L.A. 1979. Climates throughout geologic time. Elsevier Scientific Publishing Company, Amsterdam, 310 pp.

Greenwood, D.R. and Wing, S.L. 1995. Eocene continental climates and latitudinal temperature gradients. Geology, 23, 1044-1048.

Hallam, A. 1985. A review of Mesozoic climates. Journal of the Geological Society, 142, 433-445.

Hallam, A. 1994. Jurassic climates as inferred from the sedimentary and fossil record. In: Allen, J.R.L., Hoskins, B.J., Sellwood, B.W., Spicer, R.S. and Valdes, P.J. (eds.), Palaeoclimates and their modelling: with special reference to the Mesozoic Era. Chapman and Hall, London, 79-88.

Haq, B.U. 2014. Cretaceous eustasy revisited. Global and Planetary Change, 113, 44-58.

Harley, M.M. 2006. A summary of fossil records for Arecaceae. Botanical Journal of the Linnean Society, 151, 39-67.

Herngreen, G.F.W. 1973. Palynology of Albian-Cenomanian strata of borehole 1-QS-1-MA, state of Maranhao, Brazil. Pollen et spores, 15, 515-555.

Herngreen, G.F.W. 1980. Cretaceous microfloral provinces. Berliner geowissenschaftliche Abhandlungen, A, 19, 7982.

Herngreen, G.F.W. and Dueñas Jimenez, H. 1990. Dating of the Cretaceous Une Formation, Colombia and the relationship with the Albian-Cenomanian African-South American microfloral province. Review of Palaeobotany and Palynology, 66, 345-359.

Herngreen, G.FW., Kedves, M., Rovina, L.V. and Smirnova, S.B. 1996. Cretaceous palynofloral provinces: a review. In: Jansonius, J. and Mc Gregor, D.C. (eds.), Palynology: Principles, and Applications. American Association of Stratigraphic Palynologists Foundation, Texas, 3, 11571188.

Hylander, K., Dynesius, M., Jonsson, B.G. and Nilsson, C. 2005. Substrate form determines the fate of bryophytes in riparian buffer strips. Journal of Applied Ecology, 15, 674-688.

Ickert-Bond, S.M. and Renner, S.S. 2016. The Gnetales: recent insights on their morphology, reproductive biology, chromosome numbers, biogeography, and diver- 
gence times. Journal of Systematics and Evolution, 54, 1-16.

Kenrick, P. and Crane, P.R. 1997. The origin and early evolution of plants on land. Nature, 389, 33-39.

Kidder, D.L. and Worsley, T.R. 2012. Human-induced hothouse climate?. GSA Today, 22 (2), 4-11.

Kubitzki, K., 1990. Gnetaceae with single order Gnetales. In: Kramer, K.U., Green, P.S. (Eds.), The Families and Genera of Vascular Plants. Vol. I Pteridophytes and Gymnosperms. Springer, pp. 378-391.

Kujau, A., Heimhofer, U., Hochuli, P., Pauly, S., Morales, Ch., Adatte, Th., Föllmi, K., Ploch, I. and Mutterlose, J. 2013. Reconstructing Valanginian (Early Cretaceous) mid-latitude vegetation and climate based on spore-pollen assemblages. Review of Palaeobotany and Palynology, 197, 50-69.

Leanza, H. and Hugo, C.A. 2011. Las formaciones La Amarga y Lohan Cura (Cretácico Temprano) en el depocentro de Picun Leufú. In: Leanza, H.A., Arregui, C., Carbone, O., Danieli, J.C. and Vallés, J.M. (eds.), Geologia y Recursos Naturales de la Provincia de Neuquén. Relatorio XVIII Congreso Geológico Argentino, Buenos Aires, 223-230.

Liang, M. M., Bruch, A., Collinson, M., Mosbrugger, V.,. Li Ch.-S., Sun Q.-G. and Hilton, J. 2003. Testing the climatic estimates from different palaeobotanical methods: an example from the Middle Miocene Shangwang flora of China. Palaeogeography, Palaeoclimatology, Palaeoecology, 198, 279-301.

Martínez, L., Archangelsky, S., Prámparo, M. and Archangelsky, A. 2016. Early Cretaceous Palm pollen tetrads from Patagonia, Argentina. Cretaceous Research, 59, 129-139.

McLoughlin, S., Jansson, I.-M. and Vajda, V. 2014. Megaspore and microfossil assemblages reveal diverse herbaceous lycophytes in the Australian Early Jurassic flora. Grana, 53, 22-53.

Medina, F., Archangelsky, S., Guler, V., Archangelsky, A. and Cárdenas, O., 2008. Estudio bioestratigáfico integrado del perfil La Horqueta (límite Aptiano-Albiano), lago Cardiel, Patagonia, Argentina. Revista del Museo Argentino de Ciencias Naturales n.s. 10, 273-289.

Mego, N. and Prámparo, M.B. 2013. Esporas triletes verrrucosas de la Formación Lagarcito (Albiano?) Sierra de Guayaguas, Provincia de San Juan, Argentina. Análisis bioestratigráfico. Revista Brasilera de Paleontología, 16 (3), 427-440.

Mejía-Velásquez, P.J., Dilcher, D.L., Jaramillo, C., Fortini, L.B. and Manchester, S.R. 2012. Palynological composition of a Lower Cretaceous South American Tropical sequence: Climatic implications and diversity comparisons with other latitudes. American Journal of Botany, 99, 18191827.

Mishler, B.D. 2001. Book review: The biology of bryophytes. Bryophytes aren't just small tracheophytes. American Journal of Botany, 88, 2129- 2131.

Nagalingum, N.S., Drinnan, A.N., Lupia, R. and McLoughlin, S. 2002. Fern spore diversity and abundance in Australia during the Cretaceous. Review of Palaeobotany and Palynology, 119 (1), 69-92.

Narváez, P.L. and Sabino, I. 2008. Palynology of the Las
Curtiembres Formation (Late Cretaceous, Salta Group Basin), Las Conchas Creek area, northwestern Argentina. Ameghiniana, 45 (2), 473-482.

Narváez, P., Mego, N. and Prámparo, M.B. 2013. Cretaceous cicatricose spores from north and central-western Argentina. Taxonomic and biostratigraphic discussion. Palynology, 38 (2), 202-217.

Narváez, P. L., Prámparo, M.B. and Sabino, I. 2014. First palynologic record of the Cretaceous La Yesera Formation (Salta Group) Northwestern Argentina. Revista Brasilera de Paleontologia, 17 (2), 141-156.

Narváez, P., Vento, B., Mego, N., Puebla, G. and Prámparo, M. 2016. Fern diversity and comparative analysis of Cretaceous formations in Argentina. XIV International Palynological Congress, Salvador, Brasil, 109.

Nordt, L., Atchley, S. and Dworkin, S. 2003. Terrestrial evidence for two greenhouse events in the Latest Cretaceous. GSA Today, 4-9.

Page, C.N. 2002. Ecological strategies in fern evolution: a neopteridological overview. Review of Palaeobotany and Palynology, 119 (1), 1-33.

Palazzesi, L. and Barreda, V. 2007. Major vegetation trends in the Tertiary of Patagonia (Argentina): a qualitative paleoclimatic approach based on palynological evidence. Flora, 202, 328-33.

Papú, O.H. 1989. Estudio palinologico de la Formación Paso del Sapo (Cretácico Superior), Valle medio del Rio Chubut. Granos de Polen, consideraciones estadísticas, paleoecologicas y paleoambientales. Ameghiniana, 25 (3), 193-202.

Papú, O.H. 1997. Nueva especie de Grapnelispora del Campaniense-Masstrichtiense, Provincia de Mendoza, Argentina. Inferencias filogenéticas, paleobiogeográficas y paleoambientales. Revista Española de Paleontologia, 12, 197-205.

Pirrie, D., Marshall, J.D., Doyle, P. and Riccardi, A.C. 2004. Cool early Albian climate: new data from Argentina. Cretaceous Research, 25, 27-33.

Pons, D.B. 1988. Le Meésozoïque de Colombie. Macroflores et microflores. Cahiers de Paléontologie, Editions du Centre National de la Recherche Scientifique, Paris, 168 pp.

Povilauskas, L. 2011. Palinología de la Formación Monte Chico (Cretácico Tardío) de la Provincia de Santa Cruz, Argentina: Esporas. Revista Brasileira de Paleontología, $14,255-268$.

Povilauskas, L. 2012. Palinología de la Formación Monte Chico (Cretácico Tardío) de la Provincia de Santa Cruz, Argentina: Gimnospermas. Revista Brasileira de Paleontología, 15, 85-94.

Povilauskas, L. 2013. Palinología de Angiospermas de la Formación Monte Chico (Cretácico Tardío) de la Provincia de Santa Cruz, Argentina. Revista Brasileira de Paleontología, 16, 115-126.

Prámparo, M.B. 1990. Palynostratigraphy of the Lower Cretaceous of the San Luis Basin, Argentina. Its place in the Lower Cretaceous floral provinces pattern. Neues Jahrbuch Geologie und Palaontologie Abhandlungen, 181 (1-3), 247-258.

Prámparo, M.B. 1994. The Lower Cretaceous microflora of La Cantera Formation, San Luis Basin: Its correlation 
M. B. Prámparo, et al., 2018. Cretaceous climatic reconstruction from Argentina based on... Boletín Geológico y Minero, 129 (4): $615-631$

with other cretaceous microfloras of Argentina. Cretaceous Research, 15, 193-203.

Prámparo, M.B. 2012. Non-marine Cretaceous palynomorph biostratigraphy of Argentina. A brief summary. Journal of Stratigraphy, 36 (2), 212-228.

Prámparo, M.B. and Volkheimer, W. 1996. Datos palinológicos de la Formación Agrio, Cretácico Inferior, en el Cerro La Parva, Neuquén, Argentina. XIII Congreso Geológico Argentino and III Congreso de Exploración de Hidrocarburos, Buenos Aires, 5, 69-73.

Prámparo, M.B. and Volkheimer, W. 1999. Palinología del Miembro Avilé (Formación Agrio, Cretácico Inferior) en el cerro La Parva, Neuquén. Ameghiniana, 36, 217-227.

Prámparo, M.B. and Volkheimer, W. 2000. Palynology of the upper member of Agrio Formation (Cerro de la Parva locality), Neuquén Province, Argentina. Geowissenschaftliches Lateinamerika-Kolloquium, Stuttgart, 33.

Prámparo, M.B. and Volkheimer, W. 2002. Nuevos hallazgos de palinomorfos en la Formación La Amarga, Miembro Bañados de Caichigüe, Cuenca Neuquina sudoriental, Argentina. Ameghiniana, 39, 395-404.

Prámparo, M.B., Ballent, S.C., Gallego, O.F. and Milana, J.P. 2005. Paleontología de la Formación Lagarcito (Cretácico inferior), en la provincia de San Juan, Argentina. Ameghiniana, 42 (1), 93-14.

Price, G.D. 1999. The evidence and implications of polar ice during the Mesozoic. Earth Science Reviews, 48, 183210.

Pryer, K.M., Schuettpelz, E., Wolf, P.G., Schneider, H., Smith, A.R. and Cranfill, R. 2004. Phylogeny and evolution of ferns (monilophytes) with a focus on the early leptosporangiate divergences. American Journal of. Botany, 91, 1582-1598.

Puebla, G.G., Mego, N. and Prámparo, M.B. 2012. Asociacion de briofitas de la Formación La Cantera, Cuenca de San Luis, Argentina. Ameghiniana, 49, 217229.

Puebla, G.G., Prámparo, M.B. and Gandolfo, M.A. 2015. Aquatic ferns from the Upper Cretaceous Loncoche Formation, Mendoza, central-western Argentina. Plant Systematic Evolution, 301, 577-588.

Qiu, Y.L., Li, L., Wang, B., Chen, Z., et al. 2006. The deepest divergences in land plants inferred from phylogenomic evidence. Proceedings of the National Academy of Sciences, 103 (42), 15511-15516.

Quattrocchio, M.E. and Volkheimer, W. 1985. Estudio palinológico del Berriasiano en la localidad Mallín Quemado, provincia de Neuquén, Argentina. Ameghiniana, 21, 187204.

Quattrocchio, M.E., Volkheimer, W., Borromei, A.M. and Martínez, M.A. 2011. Changes of the palynobiotas in the Mesozoic and Cenozoic of Patagonia: a review. Biological Journal of the Linnean Society, 103, 380-396.

R Core Team. 2015. R: A language and environment for statistical computing. $\mathrm{R}$ Foundation for Statistical Computing, Vienna, Austria. URL http://www.Rproject.org/.

Richardson, D.H.S. 1981. The biology of mosses. Blackwell Scientific, Oxford, 220 pp.
Rydin, C. and Hoorn, C. 2016. The Gnetales: past and present. Grana, 55, 1-4.

Rydin, C., Khodabandeh, A. and Endress, P.K. 2010. The female reproductive unit of Ephedra (Gnetales): comparative morphology and evolutionary perspectives. Botanical Journal of the Linnean Society, 163, 387-430.

Sabino, I.F. 2004. Estratigrafía de la Formación La Yesera (Cretácico): Base del relleno sinrift del Grupo Salta, noroeste argentino. Revista de la Asociación Geológica Argentina, 59, 341-359.

Scasso, R.A., Aberhan, M., Ruiz, L., Weidemeyer, S., Medina, F.A. and Kiessling, W. 2012. Integrated bio- and lithofacies analysis of coarse-grained, tide-dominated deltaic environments across the Cretaceous/Palaeogene boundary in Patagonia, Argentina. Cretaceous Research, 36, 37-57.

Scotese, C.R., Boucot, A.J. and McKerrow, W.S. 1999. Gondwanan palaeogeography and palaeoclimatology. Journal of African Earth Sciences, 28, 99-114.

Schrank, E. 2010. Pollen and spores from the Tendaguru Beds, Upper Jurassic and Lower Cretaceous of southeast Tanzania: palynostratigraphical and paleoecological implications. Implications. Palynology, 34, 3-42.

Sellwood, B.W. and Valdes, P.J. 2006. Mesozoic climates: General circulation models and the rock record. Sedimentary Geology, 190, 269-287.

Simpson, M.G. 2006. Plant Systematics. Elsevier Academic Press, Nueva York, 599 pp.

Skelton, P.W. 2003. The Cretaceous world. The Open university, Cambridge University Press, Cambridge, 360 pp.

Skog, J.E. 2001. Biogeography of Mesozoic leptosporangiate ferns related to extant ferns. Brittonia, 53 (2), 236269.

Smith, A.R., Pryer, K.M., Schuettpelz, E., Korall, P., Schneider, H. and Wolf, P.G. 2006. A classification for extant ferns. Taxon, 55 (3), 705-731.

Srivastava, S.K. 1976. The fossil pollen genus Classopollis. Lethaia, 9, 437-457

Tosolini, A.M.P., McLoughlin, S, Wagstaff, B.E., Cantrill, D.J. and Gallagher, S.J. 2015. Cheirolepidiacean foliage and pollen from Cretaceous high-latitudes of southeastern Australia. Gondwana Research, 27, 960-977.

Taylor, T.N., Taylor, E. and Krings, M. 2009. Paleobotany: the biology and evolution of fossil plants. Academic Press, New York, 1199 pp.

Upchurch, G.R. and Doyle J.A. 1981. Paleoecology of the Conifers Frenelopsis and Pseudofrenelopsis (Cheirolepidiaceae) from the Cretaceous Potomac Group of Maryland and Virginia. Geobotany, 2, 167-202.

Vakrameev, V.A., 1981. Pollen Classopollis: indicador of Jurassic and Cretaceous climate. The Palaeobotanist, 28-29, 301-307.

Vallati, P. 1995. Una microflora con Afropollis (polen de angiosperma) en el Cretácico Inferior de la Cuenca Neuquina. VI Congreso Argentino de Paleontología y Bioestratigrafía, Trelew, 277-290.

Van Konijnenburg-van Cittert, J.H.A. 2002. Ecology of some late Triassic to early Cretaceous ferns in Eurasia. Review of Palaeobotany and Palynology, 119 (1), 113-124. 
Veiga, G.D., Spaletti, L.A. and Schwarz, E. 2011. El Miembro Avilé de la Formación Agrio (Cretácico Temprano). In: Leanza, H.A., Arregui, C., Carbone, O., Danieli, J.C. and Vallés, J.M. (eds), Geologia y Recursos Naturales de la Provincia de Neuquén. Relatorio XVIII Congreso Geológico Argentino, 161-173.

Villar de Seoane, L. and Archangelsky, S. 2014. Estudios palinológicos del Grupo Baqueró (Cretácico Inferior), provincia de Santa Cruz, Argentina: X. Polen de Gymnospermae y Apéndice Final. Revista del Museo Argentino de Ciencias Naturales, 16 (1), 33-44.

Volkheimer, W. and Prámparo, M.B. 1993. Primeros datos palinológicos de la Formación Tordillo (Kimmeridgiano), Localidad Chacay-Melehue, Cuenca Neuquina, Argentina. XII Congreso Geológico Argentino, Mendoza, 2, 327-333.
Volkheimer, W. and Salas, A. 1975. Die älteste Angiospermen- Palynoflora Argentiniens von der Typuslokalität der unterkretazischen Huitrín- Folge des Neuquén-Beckens. Mikroflorische Assoziation und biostratigraphische Bedeutung. Neues Jahrbuch fur Geologie und Paläontologie, Monatshefte 7, 424-436.

Wang, Z.Q. 2004. A new Permian gnetalean cone as fossil evidence for supporting current molecular phylogeny. Annals of Botany, 94, 281-288.

Wang, X. and Zheng, S. 2010. Whole fossil plants of Ephedra and their implications on the morphology, ecology and evolution of Ephedraceae (Gnetales). Chinese Science Bulletin, 55, 1511-1519.

Watson, J. 1977. Some Lower Cretaceous conifers of the Cheirolepidiaceae from the U.S.A. and England. Palaeontology, 20, 715-749.

Recibido: junio 2017

Revisado: diciembre 2017

Aceptado: febrero 2018

Publicado: diciembre 2018 
